\title{
Measuring Customer Satisfaction with the Influence of Islamic Attributes of Destination in Jordan
}

\author{
Mustafa H. Al Shamaileh ${ }^{1}$ \& Ahmad Salih Mheidi Alnaser ${ }^{2}$ \\ ${ }^{1}$ Faculty of Business, Royal University for Medical Sciences, Amman, Jordan \\ ${ }^{2}$ Faculty of Business, Amman Arab University, Amman, Jordan \\ Correspondence: Ahmad Salih Alnaser, Faculty of Business, Amman Arab University, Amman, Jordan.
}

\author{
Received: March 16, 2018 Accepted: April 27, $2018 \quad$ Online Published: May 14, 2018 \\ doi:10.5539/jms.v8n2p33 URL: https://doi.org/10.5539/jms.v8n2p33
}

\begin{abstract}
The research sought to ascertain which Islamic Attributes are fundamental to Muslim tourists while they were visiting Jordan. Furthermore, the impacts that Islamic Attributes have on promoting Jordan as an Islamic destination were also studied. It was anticipated that the research would become an integral part of Islamic tourism. A self-administered questionnaire was used to collect data from national and international Muslim tourists in various regions of Jordan. This was undertaken to determine how Islamic Attributes affect the choice of an individual's destination. Data was collected utilizing an internationally accepted measurement tool, Structural Equational Modelling (SEM). 370 questionnaires were entered and analyzed by AMOS 20; the variance is 0.32 for overall tourists' satisfaction.
\end{abstract}

Keywords: perceived value, customer expectations, Islamic attributes, customer satisfaction

\section{Introduction}

Tourism over the decades has become one of the increasing and fastest flourishing sectors internationally. It plays a fundamental role in the Jordanian economy, stimulating the enhancement of other economies (Mahafzah, 2015). In 2013, the travel and tourism industry surpassed retail, manufacturing, communications and financial services (Abuamoud, Libbin, Green, \& Al Rousan, 2014). The industry has increased its overall contribution to Gross Domestic Profit by 3\% worldwide. One in eleven positions in Jordan is now supported by the travel and tourism infrastructure. More than $10 \%$ of all new employment posts created in 2015 were in the travel and tourism sector. The aim of previous economic research conducted in 2013 by The World Travel and Tourism Council was to highlight the importance of the tourism industry in Jordan (Jordan, Vogt, Kruger, \& Grewe, 2013). The Ministry of Tourism and Antiquities in Jordan claimed that the industry's beneficence was USD6.6 trillion in GDP and represented 9\% of the overall GDP (Al-Najjar, 2015).

Various promotional programmes have been utilised to attract those Muslim tourists planning to travel to perform the annual Haj pilgrimage in Saudi Arabia. These tourists then proceed with their religious holiday by travelling to Palestine and Jordan (Isaac, 2015). Using the theoretical, empirical researches and analysis using SEM, will ascertain Customer Satisfaction for tourists. With this knowledge, Jordan could have the opportunity to enhance this investment like other nations which started and succeeded in the hospitality industry (Albarq, 2013).

The problem statement of this research can be tolerated towards Islamic Attributes as a moderating influence on Customer Satisfaction. It is constructed on the association between Customer Expectations and Perceived Value in Jordanian tourist sites. The study will use the theory of planned behaviour and the SEM method.

However, the above limitations are less significant compared to the importance of carrying out this type of study. Research should be carried out frequently to monitor service quality and discover Customer Satisfaction levels. This will aid the various travel and tourism institutions to make necessary adjustments in cases of weaknesses. Accordingly the primary objective of this study is to understand Muslim tourists' attitudes towards satisfaction by focusing on Jordan's Islamic Attributes of destination which can be crucial to the Islamic tourist industry.

\section{Literature Review}

Tourism in Jordan plays a crucial role in the nation's economy and makes an outstanding contribution to the 
nation's GDP in comparison with other areas of the country's economy. In 2013, tourism's beneficence to the Jordanian economy was ascertained to be around USD3.4 billion and accounted for approximately $12.4 \%$ of Jordan's GDP. As a result, new employment was created and afforded the local economy with hard currency (Al-Ajloni, 2016). Tourism is pivotal to the nation's national economy and is the country's greatest export market. Moreover, the tourism industry in the nation is the second largest private sector employer and producer of foreign exchange (Vargas et al., 2016).

Halal tourism is a contemporary product in the tourism industry. According to opinions, it is felt that Muslim families travelling to Muslim nations should be afforded the benefit that hotels and airlines do not serve alcohol or pork. It has also been claimed that Muslim families should be provided with gender segregated areas in swimming pools, beaches, health facilities and on modes of transport. Suggestions have been made that copies of Al Qur'an be placed in the pockets of airline seats (Battour, Ismail, Battor, \& Awais, 2017). According to Battour (2010), Islamic Attributes are fundamental to Muslims when selecting their travel destinations. Religion can impinge motivation and tourists' satisfaction. Furthermore, Islamic Attributes can have a decisive attitude on Muslim tourists (Samsudin, 2017). Jordan has Muslim and non-Muslim tourists arriving from other nations. The former arrive with distinct perspectives and behaviors which can be satiated with divergent attributes (Qaddahat et al., 2017).

Jordan is renowned for having prominent Islamic Attributes and this study will endeavor to determine Muslim tourists' perceptions regarding their satisfaction when they visit an alien Muslim nation (Eid \& El-Gohary, 2015). One of the most fundamental sectors attracting millions of tourists annually to different nations is religious tourism for Muslim and Christians (El-Gohary, 2014). It is one of the earliest types of tourism and endeavors to undertake religious rituals performed by Muslims especially Umrah and Haj and to visit the shrines of Jerusalem. Likewise, Christians visit the holy locations of Christianity and Islam (Katz, 2005). Jordan has numerous locations that draw Muslims and non-Muslims alike. In Jordan the Islamic religion is personified by the existence of many shrines attributed to companions and prophets (Moaddel, 2002).

\section{Research Theoretical Model}

Numerous researches have examined the impact of many attributes on motivational factors. Some determined attributes having an impact on push motivational factors are; "Relaxation", "Knowledge Gaining", "Need for Adventure and Excitement", "Family Togetherness", "Health" and "Social Communication and Interaction" (Fornell, 1992; Han et al., 2010; Gunnell et al., 2014; Harahsheh \& Haddad, 2016). In addition, there are many identifiable attributes to influence tourists' pull motivations, among them being "Quality Beaches", "Outstanding Scenery", "Historical Places", "Shopping Facilities" and "Safety" (Kristensen et al., 2000; Mok et al., 2013; Tosun et al., 2015; Yuen \& Cheng, 2015). The current research is the most recent study in this field and is primarily related to Islamic Attributes of destination. The study also demonstrates how the attributes affect other variables; Customer Expectation, Islamic Attributes and Perceived Value on Customer Satisfaction. This study used the variable combined with the need of religion which is different than the need of food products or tangible services.

A. Customer Satisfaction is the state of satisfaction dependent on a number of psychological and physical variables. These correlate with satisfaction behaviors such as return and recommend rate. The level of satisfaction is based on other factors such as other products against which the customer can compare the organization's products (Gunnell, Crocker, Mack, Wilson, \& Zumbo, 2014).

B. Islamic Attributes of Destinations are based on religion and religiosity as recognized factors influencing behavior in various social settings. Therefore, there has been a recommendation to study the effect of catering for the religious needs of tourists to gain a high level of satisfaction. This could affect future behavior, tourist product preferences and repeat visits (Battour \& Ismail, 2011).

C. The factor of Islamic Attributes of Destination variables in general terms; a moderator is a qualitative (sex, race, class) or quantitative (level of reward) variable that affects the direction and/or strength of the relation between an independent or predictor variable and a dependent or criterion variable, specifically within a correlational analysis framework. A moderator is also a third variable that affects the zero-order correlation between two other variables. In more familiar analysis of variance (ANOVA) terms, a basic moderator effect can be represented as an interaction between a focal independent variable and a factor that specifies the appropriate conditions for its operation Hair et al. (2006).

D. The theory of planned behavior asserts that attitude is the key to understanding behavior. However, research in the late 1960s illustrated that attitude is often a poor predictor of actual behaviors (Quintal et al., 2010). More recent research has shown that an important condition for the relationship between attitudes and behaviors is the 
principle of compatibility. If the measure of attitude matches the measure of the behavior in terms of the level of generality or specificity, high correlations between attitude and behavior are found (Beck \& Ajzen, 1991). The relationship between attitude and behaviors has also been supported by recent research into products.

From an Islamic perspective to the importance of tourism, the literature review displays research in the field of tourism specifically those conversant with pull and push motivational factors.

\section{Research Findings}

In terms of gender, $62.9 \%$ of respondents are male and $37.1 \%$ female. The classification of samples in terms of marital status presents that $45 \%$ of respondents are single, $55 \%$ married. Regarding nature of visit, $67.8 \%$ are pleasure and $32.2 \%$ business. By age, 22.5\% are between 18-24 years old, 25.9\% 25-34 years, 35\% 35-44 years, $12 \%$ 45-54 years and $4.6 \%$ above 55 years. By education level, $43.5 \%$ of the respondents have a university degree, $19.7 \%$ are postgraduates, $21.6 \%$ are secondary and intermediate and $15.2 \%$ are diploma. In terms of monthly income, $22.2 \%$ claimed that they earn less than USD1000, whereas $24.9 \%$ of respondents claimed to earn USD1000-1500, 24.3\% earn USD1501-2000, 19.7\% earn USD2001-3000, and 8.9\% earn in excess of USD3000. By the visit, $21.1 \%$ are alone, $11.1 \%$ with parents, $45.7 \%$ with family, $18.6 \%$ with friends, and $3.5 \%$ are others. By religiosity, $21.1 \%$ categorize themselves as null (secular), $4.6 \%$ as low religious, $25.3 \%$ as neutral or moderate, $33.7 \%$ as religious and $15.3 \%$ as very religious.

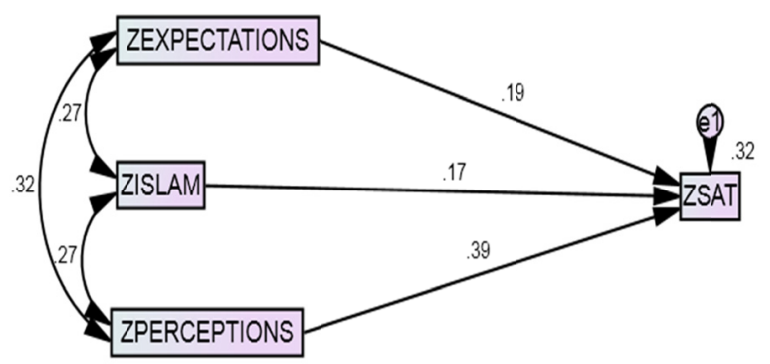

Figure 1. Islamic attributes effect

Figure 1 was the first stage of the testing model with the effect of influence. The results shown above are the positive relationships between expectation and Islamic attributes .27 as the relationship between Perceived Value and Islamic Attributes, the relationship between the independent variables relationship was .32. The relationship between CE and CS was 0.19 followed by 0.39 for the relationship between PV and CS, the Islamic Attributes Moderator 0.17 on CS. Finally, e1 was 0.32 in the direct relationship which is less than the following test with the moderating effect and all hypotheses were supported as shown in Table 1.

Table 1. Path coefficient and significant t-value

\begin{tabular}{llllcrc}
\hline & & & Path coefficient & t-value & Sig & Result \\
\hline ZSAT & $<---$ & ZEXPECTATIONS & 0.189 & 4.072 & .000 & SUPPORTED \\
ZSAT & $<---$ & ZISLAM & 0.175 & 3.831 & .000 & SUPPORTED \\
ZSAT & $<---$ & ZPERCEPTIONS & 0.387 & 8.334 & .000 & SUPPORTED \\
\hline
\end{tabular}

For calculating the $\mathrm{f} 2$, the equation suggested by Tabachnick \& Fidell (2007) has been used. This procedure also reveals that the (e1) has been increased and this increase has impacted effect positively.

Islamic Attributes on Destinations were found to have a significant effect on Customer Satisfaction in tourist sites in Jordan. The discussion of this significant relationship follows.

\section{H1: Islamic attributes on destinations have an influence on customer satisfaction.}

One of the objectives of this study was to empirically investigate the relationship between Islamic Attributes on Destinations and Customer Satisfaction. The study found the relationship between Customer Expectations and Customer Satisfaction to be positively significant. The findings are in line with that reported by previous studies (Battour \& Battor et al., 2014; Battour \& Ismail et al., 2014). This relationship was expected because tourists had 
already selected Jordan as a country to visit and the Islamic Attributes on the facilities available to them. The current research has provided empirical evidence that Islamic Attributes on Destinations is one of the factors tourists will think about before choosing their preferable destinations. From the Islamic Attributes on Destinations, it depends on a tourist's perceptions and the different suppliers. It is known that Customer Perceived Value has a significant relation on customer satisfaction in Jordan.

H2: Islamic attributes have moderating influence over the association of customer expectations and customer satisfaction.

One of the objectives of this study was to empirically investigate the relationship between Islamic Attributes on Destinations and Customer Satisfaction. The study found the relationship between Customer Expectations and Customer Satisfaction to be positively significant. This finding is in line with that reported by previous studies. The relationship was measured as a moderator on pull motivations (Farahdel, 2011). Later, several studies used the Islamic Attributes on Destination or Halal tourism as parameters (Battour \& Ismail, 2015). The present study has provided empirical evidence that Customer Expectation is one of the factors tourists will think about prior to choosing their preferred destinations. From the predicted image tourists already have in their mind depends on a tourist's perceptions. Islamic Attributes have moderating influence over the association of Customer Expectations and Customer Satisfaction.

H3: Islamic attributes have moderating influence over the association of customer perceived value and customer satisfaction.

One of the objectives of this study was to empirically investigate the relationship between Islamic attributes on destinations moderating customer perceived value customer satisfaction. The study found the relationship between Islamic Attributes has moderate influence over the association of Customer Perceived value and Customer satisfaction to be positively significant. This finding is in line with that reported by previous studies the relationship was measured as a moderator on push motivations.Later on several studies used the Islamic attributes as an Islamic destination or Halal tourism as (Battour \& Ismail, 2015).

\section{Discussion}

This research has provided empirical evidence that Customer Expectations is one of the factors tourists will think about before they choose their preferred destinations. From the predicted image tourists already have in their mind which is different depends on tourist's perceptions. Islamic Attributes have moderating influence over the association of Customer Perceived Value and Customer Satisfaction. When people are asked about their purpose for traveling, they give one or more reasons; visiting friends, exploring a new destination, finding job opportunities, experiencing new cultures. Sometimes people seek relaxation when deciding to travel as they want to escape from the stressful environment of their work or home. Others give the primary reason for traveling as having fun, being adventurous and entertained.

Jordan has strong Islamic attributes comparable to other countries. The nation enacts different laws and limitations for women's and men's appearance, relations and communication in the society based on Islamic practices (Haddad, 2015). In this study, it has been attempted to examine Muslim tourists' overall opinions and attitudes about their visit to Jordanian sites so as to clarify the extent to which Jordan's Islamic attributes have had an impact on their overall satisfaction.

Data analysis results reveal that Jordan's Muslim tourists' Customer Perceived Values factors such as, experiencing adventure, seeing different culture, visiting new places etc., have a positive impact on their satisfaction. Moreover, it can be concluded that Jordan's Customer Expectations factors such as natural scenery, rich culture and shopping facilities also have a positive relationship with Muslim tourists' overall satisfaction. This means that these natural and historical sceneries as well as shopping facilities are strong indicators to drive tourists to Jordan.

Considering Islamic Attributes of Jordan, it establishes a positive but weak impact on the relationship between the motivational factors and the tourists' satisfaction. In other words, Islamic Attributes moderates and strengthens the relationship between tourist motivational factors and their satisfaction. However, it has a minor effect on this relationship, thereby Jordan's Islamic attributes will impact tourists' satisfaction but it is not the main reason for their overall satisfaction. In fact, some of the respondents admitted that when they had decided to choose Jordan as their destination, they knew that the country as an Islamic destination. Therefore, the respondents already expected it to have Islamic Attributes. The availability of these Islamic Attributes in Jordan may not be their main concern but the natural scenery and historical places, shopping facilities and cleanliness could be an incentive for them. In some cases where the readiness of physical activities was demanding among 
some Muslim tourists, the availability of Islamic Attributes was emphasized by them.

\section{Research Summary}

This section discusses the findings of this study followed by a discussion of the relationship among the research variables used to achieve the objective of this study. A description of the contributions in this study is also highlighted.

Nowadays, tourism industries try to assure their tourists' satisfaction since an individual can be a channel for bringing more tourists into a country. Different countries lure tourists based on their attractions and sceneries, historical places or religious sites. It has been attempted to present all the data analysis results. Based on these results, all the hypotheses have been supported meaning that both push motivational factors and pull motivational factors examined in this research have had a significant impact on Jordan's Muslim tourists' satisfaction. Moreover, the Islamic Attributes of Jordan have also affected these results to some extent. The final structural model has been also illustrated.

\section{Limitation of Study}

This research had some methodological and theoretical limitations but has created several opportunities for future researchers. Like previous researchers, this study also had challenges and had some limitations too. The major challenge was the data collection as the current researcher was not permitted to collect data freely due to safety and security reasons in Jordan. The majority of Jordanian hotel managers were not helpful and supportive and in most cases refused to permit the questionnaires to be distributed. The managers referred the researcher to a department in the hotel administrated by the police. In addition, a security environment was dominant everywhere which was an obstacle for collecting data without restrictions. It should be noted that tourists were extremely supportive.

\section{Recommendations for Further Research}

This research could have been more comprehensive if the questionnaires had been distributed among Muslim and non-Muslim tourists which could be suggested for future research. A quantitative research could also be undertaken to collect other factors vital for tourists.

\section{Conclusion}

Considering Islamic Attributes of Jordan, there is a positive but weak impact on the relationship between the motivational factors and the tourists' satisfaction. In other words, Islamic Attributes moderates and strengthens the relationship between tourist motivational factors and their satisfaction. However, it has a minor effect on this relationship, meaning that Jordan's Islamic Attributes will impact tourists' satisfaction but it is not the main reason for their overall satisfaction.

\section{References}

Abuamoud, I. N., Libbin, J., Green, J., \& ALRousan, R. (2014). Factors affecting the willingness of tourists to visit cultural heritage sites in Jordan. Journal of Heritage Tourism, 9(2), 148-165. https://doi.org/10.1080/1743873X.2013.874429

Al-Ajloni, A. A. G. (2016). Tourism Development in Jordan: a Study of Tourism Awareness Among Students of Private Jordanian Universities Case Study: Irbid and Jadara Universities. Revue Académique des Études Sociales et Humaines, (15), 48.

Albarq, A. N. (2013). Measuring the impacts of online word-of-mouth on tourists' attitude and intentions to visit Jordan: An empirical study. International Business Research, 7(1), 14. https://doi.org/10.5539/ibr.v7n1p14

Al-Najjar, B. (2015). Does ownership matter in publicly listed tourism firms? Evidence from Jordan. Tourism Management, 49, 87-96. https://doi.org/10.1016/j.tourman.2015.02.008

Battour, M. M., Ismail, M. N., \& Battor, M. (2010). Toward a halal tourism market. Tourism Analysis, 15(4), 461-470. https://doi.org/10.3727/108354210X12864727453304

Battour, M., Ismail, M. N., \& Battor, M. (2011). The impact of destination attributes on Muslim tourist's choice. International Journal of Tourism Research, 13(6), 527-540. https://doi.org/10.1002/jtr.824

Battour, M., Ismail, M. N., Battor, M., \& Awais, M. (2017). Islamic tourism: an empirical examination of travel motivation and satisfaction in Malaysia. Current Issues in Tourism, 20(1), 50-67. https://doi.org/10.1080/13683500.2014.965665

Beck, L., \& Ajzen, I. (1991). Predicting dishonest actions using the theory of planned behavior. Journal of 
Research in Personality, 25(3), 285-301. https://doi.org/10.1016/0092-6566(91)90021-H

Eid, R., \& El-Gohary, H. (2015). Muslim tourist perceived value in the hospitality and tourism industry. Journal of Travel Research, 54(6), 774-787. https://doi.org/10.1177/0047287514532367

El-Gohary, H. (2014). Emerging research on Islamic marketing and tourism in the global economy. IGI Global.

Fornell, C. (1992). A national customer satisfaction barometer: The Swedish experience. The Journal of Marketing, 6-21. https://doi.org/10.2307/1252129

Gunnell, K. E., Crocker, P. R., Mack, D. E., Wilson, P. M., \& Zumbo, B. D. (2014). Goal contents, motivation, psychological need satisfaction, well-being and physical activity: A test of self-determination theory over 6 months. Psychology of Sport and Exercise, 15(1), 19-29. https://doi.org/10.1016/j.psychsport.2013.08.005

Hair, J. F., Black, W. C., Babin, B. J., Anderson, R. E., \& Tatham, R. L. (2006). Multivariate data analysis (Vol. 6). Upper Saddle River, NJ: Pearson Prentice Hall

Han, H., Hsu, L. T. J., \& Sheu, C. (2010). Application of the theory of planned behavior to green hotel choice: Testing the effect of environmental friendly activities. Tourism Management, 31(3), 325-334. https://doi.org/10.1016/j.tourman.2009.03.013

Harahsheh, S., \& Haddad, R. (2016). The role of the Royal Automobile Museum in tourism and heritage education in Jordan. Automobile Heritage and Tourism, 39, 223.

Isaac, R. K. (2015). Pilgrimage tourism to Palestine. The Politics and Power of Tourism in Palestine, 124.

Jordan, E. J., Vogt, C. A., Kruger, L. E., \& Grewe, N. (2013). The interplay of governance, power and citizen participation in community tourism planning. Journal of Policy Research in Tourism, Leisure and Events, 5(3), 270-288. https://doi.org/10.1080/19407963.2013.789354

Katz, K. (2005). Jordanian Jerusalem: Holy Places and National Spaces. JSTOR.

Kristensen, K., Martensen, A., \& Gronholdt, L. (2000). Customer satisfaction measurement at post Denmark: results of application of the European customer satisfaction index methodology. Total Quality Management, 11(7), 1007-1015. https://doi.org/10.1080/09544120050135533

Mahafzah, A. (2015). The impact of the national strategy for tourism on economic development in Jordan. $J$ Econ Sustain Dev, 6, 104-107.

Moaddel, M. (2002). Jordanian exceptionalism: a comparative analysis of state-religion relationships in Egypt, Iran, Jordan, and Syria. London: Macmillan.

Mok, C., Sparks, B., \& Kadampully, J. (2013). Service quality management in hospitality, tourism, and leisure. London, New York: Routledge.

Qaddahat, R., Attaalla, F., \& Hussein, M. M. (2017). Halal Tourism: Evaluating Opportunities and Challenges in the Middle East "Jordan and Egypt". International Journal of Heritage, Tourism, and Hospitality, 10(2/2).

Quintal, V. A., Lee, J. A., \& Soutar, G. N. (2010). Risk, uncertainty and the theory of planned behavior: A tourism example. Tourism Management, 31(6), 797-805. https://doi.org/10.1016/j.tourman.2009.08.006

Samsudin, S. (2017). Attitudes, Lifestyle and Social Benefits of Local Communities Towards Islamic Tourism Development in Malaysia. In Balancing Development and Sustainability in Tourism Destinations (pp. 145-155). Berlin: Springer. https://doi.org/10.1007/978-981-10-1718-6_15

Tabachnick, B. G., \& Fidell, L. S. (2007). Multivariate analysis of variance and covariance. Using Multivariate Statistics, 3, 402-407.

Tosun, C., Dedeoğlu, B. B., \& Fyall, A. (2015). Destination service quality, affective image and revisit intention: The moderating role of past experience. Journal of Destination Marketing \& Management, 4(4), 222-234. https://doi.org/10.1016/j.jdmm.2015.08.002

Vargas, M., Díaz, A. T., Murillo, S., Díaz, J. A., Trelles, S., Murillo, J. C., ... Machado Allison, C. (2016). Cosechando resultados: Honduras: logros significativos en 2015. Paper presented at the Serie Publicaciones Misceláneas (IICA) A2/JM.

Yuen, S. S., \& Cheng, C. (2015). Quality Management Measures in Food Supply Chain. 


\section{Copyrights}

Copyright for this article is retained by the author(s), with first publication rights granted to the journal.

This is an open-access article distributed under the terms and conditions of the Creative Commons Attribution license (http://creativecommons.org/licenses/by/4.0/). 